\title{
Hubungan Regulasi Diri dengan Kecemasan Menghadapi Dunia Kerja pada Mahasiswa Tingkat Akhir Universitas Syiah Kuala
}

\author{
Teuku Riki Azhari, Mirza \\ teukurikiazhari@gmail.com
}

Program Studi Psikologi, Fakultas Kedokteran, Universitas Syiah Kuala, Banda Aceh

\begin{abstract}
Mahasiswa sebagai individu yang memasuki rentang usia dewasa memiliki tugas perkembangan yaitu bekerja dan membangun karir. Persaingan dalam mendapatkan pekerjaan menimbulkan kecemasan dalam diri mahasiswa. Individu yang memiliki regulasi diri yang tinggi dapat mengontrol perilaku dan menetapkan tujuan sehingga akan berkurang rasa cemas. Penelitian ini bertujuan untuk mengetahui hubungan antara regulasi diri dengan kecemasan menghadapi dunia kerja pada mahasiswa tingkat akhir Universitas Syiah Kuala. Teknik pengambilan sampel yang digunakan adalah quota sampling. Sampel penelitian ini berjumlah seratus mahasiswa yang terdiri dari angkatan 2009 sampai dengan angkatan 2012 yang sudah menyelesaikan tugas akhir (skripsi). Penelitian ini menggunakan alat ukur yang disusun sendiri oleh peneliti berdasarkan teori Baumeister dan Heatherthon (1996) untuk regulasi diri dan teori Calhoun dan Acocela (1990) untuk kecemasan menghadapi dunia kerja. Hasil analisis data menggunakan korelasi Pearson menunjukkan bahwa terdapat hubungan negatif dan signifikan antara regulasi diri dengan kecemasan menghadapi dunia kerja pada mahasiswa tingkat akhir Universitas Syiah Kuala $(r=-0.62, p=0.00, p<0.05)$. Hal ini mengindikasikan bahwa semakin tinggi regulasi diri maka semakin rendah kecemasan menghadapi dunia kerja pada mahasiswa tingkat akhir Universitas Syiah Kuala atau sebaliknya.
\end{abstract}

Kata kunci: kecemasan menghadapi dunia kerja; mahasiswa; regulasi diri

\section{Pendahuluan}

Negara-negara anggota Assosiation of South East Asia Nation (ASEAN) memberlakukan Masyarakat Ekonomi ASEAN (MEA) pada akhir Desember 2015 lalu. MEA merupakan kesepakatan antarnegara anggota ASEAN untuk meningkatkan kualitas ekonomi kawasan dengan pilar ASEAN sebagai pasar tunggal dan berbasis produksi yang didukung dengan unsur aliran barang, jasa, investasi, aliran modal, dan tenaga kerja professional dalam satu kawasan di regional asia tenggara (Malau, 2014). MEA memberikan peluang dan tantangan yang besar bagi perkembangan regional, salah satunya adalah mengenai distribusi sumber daya manusia sebagai tenaga kerja (Abdurofiq, 2014). MEA memberikan kesempatan yang sangat besar bagi para pencari kerja karena tersedia lapangan kerja dengan berbagai kebutuhan untuk keahlian yang beraneka ragam. Namun jika ditinjau dari segi pendidikan dan produktivitas, Indonesia masih kalah bersaing dengan tenaga kerja yang berasal dari Malaysia, Singapura, dan Thailand serta fondasi industri Indonesia berada pada peringkat keempat di ASEAN (Rostanti \& Alamsyah, 2013). Sedangkan di Indonesia, persaingan antara pencari kerja sangat tinggi, terbukti dengan tingginya angka pengangguran. Pengangguran dalam suatu negara adalah perbedaan antara angkatan kerja dengan penggunaan tenaga kerja yang dibutuhkan (Sugianto, 2006).

Berdasarkan data dari Badan Pusat Statistik (2014), yang diolah dari hasil Survei Angkatan Kerja Nasional (Sakernas) dapat dilihat tingkat pengangguran di Indonesia dari tahun 2009-2013 yang mengalami fluktuasi (Tabel 1). 
Tabel 1

Data angkatan kerja, jumlah orang yang bekerja, dan pengangguran di Indonesia bulan Agustus tahun 20092013

\begin{tabular}{cccc}
\hline Tahun & $\begin{array}{c}\text { Angkatan Kerja } \\
\text { (Juta Orang) }\end{array}$ & $\begin{array}{c}\text { Bekerja } \\
\text { (Juta Orang) }\end{array}$ & $\begin{array}{c}\text { Pengangguran } \\
\text { (Juta Orang) }\end{array}$ \\
\hline 2009 & 113.83 & 104.87 & 8.96 \\
2010 & 116.53 & 108.21 & 8.32 \\
2011 & 117.37 & 109.67 & 7.70 \\
2012 & 118.05 & 110.81 & 7.24 \\
2013 & 118.19 & 110.80 & 7.39
\end{tabular}

Sumber: Survei Angkatan Kerja Nasional (Sakernas, 2014).

Data di atas menjelaskan jumlah pengangguran di Indonesia pernah mengalami penurunan dari tahun 2009 sampai dengan 2012. Akan tetapi, terjadi peningkatan jumlah pengangguran yaitu sebanyak 150 ribu jiwa dari 7,24 juta jiwa di tahun 2012 menjadi 7,39 juta jiwa di tahun 2013, dimana jumlah angkatan kerja mengalami peningkatan 14 ribu jiwa dari tahun 2012 ke 2013.

Selanjutnya, Provinsi Aceh tercatat memiliki angka pengangguran yang cukup tinggi. Data Sosial Ekonomi BPS (2015) menunjukkan tingkat pengangguran di Aceh periode Agustus 2015 berada pada peringkat kedua tertinggi di Indonesia. Dinas Ketenagakerjaan dan Mobilitas Penduduk (Disnakermobduk) Provinsi Aceh merilis pengangguran lulusan S1 di Provinsi Aceh mencapai 17.498 orang $(9.14 \%)$ (Disnakermobduk, 2015).

Tingginya angka pengangguran sebagaimana data yang dipaparkan diatas disebabkan oleh beberapa faktor. Sukidjo (2005) menyebutkan beberapa faktor yang menyebabkan pengangguran di Indonesia, salah satunya adalah keterbatasan jumlah lapangan kerja sehingga tidak mampu menampung seluruh pencari kerja. Kebijakan pemerintah yang tidak tepat dan rendahnya upaya pemerintah untuk melakukan pelatihan guna meningkatkan kualitas tenaga kerja juga menyebabkan angka pengangguran yang tinggi di Indonesia. Hal ini selanjutnya menimbulkan rasa khawatir pada mahasiswa tingkat akhir terhadap kemungkinan mereka mendapatkan pekerjaan (Saidah, 2013).

Perasaan takut tentang sesuatu yang berupa ancaman-ancaman dan kesulitan yang sebenarnya belum jelas dan tidak realistis dapat membahayakan kesejahteraan seseorang disebut dengan kecemasan (Alloy, Riskind, \& Manos, 2005). Calhoun dan Acocella (1990) menambahkan kecemasan adalah perasaan takut (nyata maupun tidak nyata) yang disertai dengan meningkatnya aktifitas fisiologis. Kecemasan pada mahasiswa ketika akan menghadapi dunia kerja selanjutnya disebut dengan kecemasan menghadapi dunia kerja.

Mahasiswa memerlukan strategi yang tepat untuk menghadapi kemungkinan yang akan terjadi di masa depan berupa motivasi internal yang berakibat pada timbulnya keinginan untuk menentukan tujuan-tujuan yang ingin dicapai serta melakukan evaluasi dan modifikasi terhadap perilaku sendiri. Hal ini dikenal dengan regulasi diri (Cervone \& Lawrence, 2012).

Regulasi diri adalah kemampuan seseorang untuk mengubah respon-respon, seperti mengendalikan impuls perilaku (dorongan perilaku), menahan hasrat, mengontrol pikiran, dan mengubah emosi (Kowalski \& Leary, 2000). Baumeister dan Heatherthon (1996) menambahkan bahwa regulasi diri merupakan upaya seseorang untuk mencegah perilaku dan respon agar tidak melenceng dan kembali pada standar norma yang memberi hasil sama. Melalui regulasi diri mahasiswa dapat mengelola kecemasan yang dimiliki dengan penetapan tujuan, 
perencanaan implementasi, dan mengawasi kemajuan diri (King, 2010).

Lutfa dan Maliya (2008), menjelaskan bahwa pengetahuan dan informasi yang merupakan bagian dari proses regulasi diri berupa akan menyebabkan kecemasan yang ada menjadi berkurang. Semakin banyak informasi yang dimiliki tentang sesuatu yang akan terjadi, maka orang tersebut akan jauh lebih tenang dalam menghadapinya. Menurut Durand dan Barlow (2007), kecemasan dapat disebabkan oleh kekhawatiran individu tentang masa depan. Lebih lanjut Carver (2004) menambahkan kecemasan dan ketakutan berkaitan dengan rendahnya tingkat kemajuan dalam mencapai tujuan dan mencegah hasil yang negatif. Melakukan evaluasi diri akan memberikan pemahaman tentang seberapa jauh capaian atau progress mahasiswa dari tujuan yang telah ditetapkan sebelumnya. Melakukan regulasi diri tersebut bisa membuat individu mengetahui kekurangan dari proses yang selama ini dilakukan, sehingga dapat mengurangi timbulnya kecemasan menghadapi dunia kerja (Rodebaugh \& Heimberg, 2005).

Berdasarkan uraian di atas, maka peneliti tertarik untuk melihat hubungan antara regulasi diri dengan kecemasan menghadapi dunia kerja pada mahasiswa tingkat akhir. Dengan demikian, hipotesis yang diajukan dalam penelitian ini adalah "terdapat hubungan antara regulasi diri dengan kecemasan menghadapi dunia kerja pada mahasiswa tingkat akhir".

\section{Metode}

\section{Jenis penelitian}

Penelitian ini merupakan penelitian kuantitatif dengan jenis penelitian korelasional dan juga merupakan penelitian cross-sectional study. Adapun populasi penelitian ini adalah seluruh mahasiswa Universitas Syiah Kuala. Teknik pengambilan sampel penelitian menggunakan teknik quota sampling. Teknik pengambilan sampel dengan cara menentukan sampel dari populasi yang mempunyai ciri-ciri tertentu sampai jumlah yang diinginkan terpenuhi (Sugiyono, 2010). Peneliti menentukan jumlah sampel penelitian yang digunakan dalam penelitian ini sebanyak seratus sampel. Adapun kriteria sampel penelitian adalah sebagai berikut:

1. Terdaftar sebagai mahasiswa aktif pada dua belas fakultas di Universitas Syiah Kuala;

2. Telah menyelesaikan ujian tugas akhir (skripsi); dan

3. Bersedia menjadi responden penelitian.

\section{Metode pengumpulan data}

Metode pengumpulan data yang digunakan adalah skala psikologi, yaitu skala regulasi diri dan skala kecemasan menghadapi dunia kerja. Skala regulasi diri dirancang dan disusun oleh peneliti berdasarkan pada komponen regulasi diri yang dikemukakan oleh Baumeister dan Heatherthon (1996), yang berjumlah tiga puluh aitem dengan menggunakan skor penilaian modifikasi skala Likert dengan empat pilihan jawaban. Sedangkan skala kecemasan menghadapi dunia kerja dirancang dan disusun oleh peneliti berdasarkan pada komponen kecemasan yang dikemukakan oleh Calhoun dan Acocela (1990) dengan jumlah aitem sebanyak tiga puluh.

\section{Teknik analisis data}

Data yang diperoleh dari penelitian ini selanjutnya dianalisis menggunakan teknik korelasi Pearson dengan menggunakan program SPSS Versi 18.0 for Windows. 


\section{Hasil}

\section{Deskripsi data regulasi diri}

Gambaran umum mengenai data penelitian untuk variabel regulasi diri dapat dilihat pada tabel berikut ini:

Tabel 2

Deskripsi data penelitian skala regulasi diri

\begin{tabular}{ccccc}
\hline \multirow{2}{*}{ Variabel } & \multicolumn{4}{c}{ Data hipotetik } \\
\cline { 2 - 5 } & Xmaks & Xmin & Mean & SD \\
\hline Regulasi diri & 80 & 20 & 90 & 83.3 \\
\hline \multirow{2}{*}{ Variabel } & \multicolumn{4}{c}{ Data empirik } \\
\cline { 2 - 5 } & Xmaks & Xmin & Mean & SD \\
\hline Regulasi diri & 80 & 43 & 59.76 & 7.182 \\
\hline
\end{tabular}

Deskripsi data hasil penelitian tersebut dapat dijadikan batasan dalam pengkategorian sampel penelitian yang terdiri dari dua kategori. Pembagian kategori sampel yang digunakan oleh peneliti yaitu pertimbangan eror standar dalam pengukuran. Menurut Azwar (2013) pertimbangan eror standar dalam pengukuran adalah deviasi standar eror yang menunjukkan besarnya variasi eror pengukuran sekelompok subjek pada kategorisasi rendah dan tinggi. Adapun kategorisasi dapat dilihat selengkapnya pada tabel berikut:

Tabel 3

Kategorisasi regulasi diri

\begin{tabular}{cccc}
\hline Skor & Kategori & Jumlah & Persentase \\
\hline $\mathrm{X}<45$ & Rendah & 5 & $5 \%$ \\
$46 \leq \mathrm{X}<54$ & $\begin{array}{c}\text { Tidak } \\
\text { Terkategorisasi }\end{array}$ & 12 & $12 \%$ \\
$55 \leq \mathrm{X}$ & Tinggi & 83 & $83 \%$
\end{tabular}

\section{Deskripsi data kecemasan menghadapi dunia kerja}

Gambaran umum mengenai data penelitian untuk variabel kecemasan menghadapi dunia kerja dapat dilihat pada tabel berikut ini:
Tabel 4

Deskripsi data penelitian skala kecemasan menghadapi dunia kerja

\begin{tabular}{ccccc}
\hline \multirow{2}{*}{ Variabel } & \multicolumn{4}{c}{ Data hipotetik } \\
\cline { 2 - 5 } & Xmaks & Xmin & Mean & SD \\
\hline $\begin{array}{l}\text { Kecemasan } \\
\text { menghadapi } \\
\text { dunia kerja }\end{array}$ & 60 & 15 & 37.5 & 12.5 \\
\hline Variabel & \multicolumn{4}{c}{ Data empirik } \\
\cline { 2 - 5 } & Xmaks & Xmin & Mean & SD \\
\hline $\begin{array}{l}\text { Kecemasan } \\
\text { menghadapi } \\
\text { dunia kerja }\end{array}$ & 60 & 15 & 44.81 & 7.140 \\
\hline
\end{tabular}

Deskripsi data hasil penelitian tersebut dapat dijadikan batasan dalam pengkategorian sampel penelitian yang terdiri dari dua kategori. Pembagian kategori sampel yang digunakan oleh peneliti yaitu pertimbangan eror standar dalam pengukuran. Kategorisasi sampel kecemasan menghadapi dunia kerja adalah sebagai berikut:

Tabel 5

Kategorisasi kecemasan menghadapi dunia kerja

\begin{tabular}{|c|c|c|c|}
\hline Skor & Kategori & Jumlah & Persentase \\
\hline $\mathrm{X}<49$ & Rendah & 52 & $52 \%$ \\
\hline $50 \leq X<56$ & $\begin{array}{c}\text { Tidak } \\
\text { Terkategorisasi }\end{array}$ & 36 & $36 \%$ \\
\hline $57 \leq X$ & Tinggi & 12 & $12 \%$ \\
\hline
\end{tabular}

Analisis terhadap data penelitian yang telah diperoleh menghasilkan koefisien korelasi sebesar -0.620 dengan $p<0.05$. Hal ini bermakna terdapat korelasi negatif yang signifikan antara regulasi diri dengan kecemasan menghadapi dunia kerja. Hal ini menunjukkan bahwa semakin tinggi regulasi diri maka semakin rendah kecemasan menghadapi dunia kerja yang dimiliki seseorang (Tabel 6).

\section{Diskusi}

Penelitian ini dilakukan untuk mengetahui hubungan antara regulasi diri dengan 
kecemasan menghadapi dunia kerja pada mahasiswa tingkat akhir Universitas Syiah Kuala. Hasil penelitian ini menunjukkan bahwa terdapat hubungan negatif dan signifikan antara regulasi diri dengan kecemasan menghadapi dunia kerja pada mahasiswa tingkat akhir Universitas Syiah Kuala. Hubungan negatif ini menunjukkan semakin tinggi regulasi diri maka semakin rendah kecemasan menghadapi dunia kerja pada mahasiswa tingkat akhir Universitas Syiah Kuala.

Tabel 6

Tabel uji hipotesis

\begin{tabular}{ccc}
\hline $\begin{array}{c}\text { Hubungan } \\
\text { antar variabel }\end{array}$ & Nilai korelasi & Signifikansi (p) \\
\hline $\begin{array}{l}\text { Regulasi diri } \\
\text { dan kecemasan }\end{array}$ & -0.620 & 0.000 \\
\hline
\end{tabular}

Hasil penelitian ini sesuai dengan yang dikemukakan oleh Klenk, Strauman, dan Higgins (2011) bahwa kegagalan kronis dari proses regulasi diri, seperti gagal dalam menentukan tujuan atau setelah menentukan tujuan tetapi gagal melakukannya, dapat berdampak pada terjadinya kecemasan. Kegagalan individu dalam menentukan tujuan masa depan dan progress yang didapat dalam mencapai tujuan yang telah ditetapkan menyebabkan munculnya simtom-simtom kecemasan dan depresi (patologis).

Hasil penelitian ini juga menunjukkan bahwa subjek penelitian yang memiliki regulasi diri tinggi adalah $83 \%$, selebihnya memiliki tingkat regulasi diri rendah yaitu sebanyak 5\%. Hal tersebut dapat diinterpretasikan bahwa subjek penelitian memiliki sikap yang terbentuk dari aspek regulasi diri yaitu memiliki standar, melakukan monitoring, dan bertindak. Fiske dan Taylor (1991) memberikan gambaran individu yang memiliki tingkat regulasi diri yang tinggi yaitu mampu menentukan tujuan dan mempertahankan motivasinya, dapat mengatur emosi dengan lebih baik, dapat memonitor kemajuan yang dicapai menuju tujuan, dan dapat mengevaluasi kesulitan yang muncul.

Hasil penelitian juga menunjukkan bahwa 52\% subjek penelitian memiliki tingkat kecemasan menghadapi dunia kerja yang rendah dan $12 \%$ memiliki tingkat kecemasan menghadapi dunia kerja yang tinggi. Hal tersebut mengindikasikan bahwa tingkat kecemasan menghadapi dunia kerja mahasiswa Universitas Syiah Kuala pada subjek penelitian ini tergolong rendah. Lestari (2006) menjelaskan bahwa dengan memiliki kemampuan (skill) yang baik, maka dapat menurunkan tingkat kecemasan individu.

Pada saat penelitian, peneliti menemui keterbatasan antara lain sampel penelitian (mahasiswa tingkat akhir) umumnya tidak lagi banyak melakukan aktivitasnya di kampus sehingga sulit ditemui. Keterbatasan lainnya adalah skala baku pada kedua variabel tidak sesuai budaya lokasi penelitian sehingga peneliti menyusun sendiri skala penelitian. Peneliti menyarankan jika penelitian dengan variabel yang sama akan dilakukan kembali, maka dianjurkan untuk menggunakan skala baku dari teori-teori yang tersebut sebelumnya.

Selanjutnya, kepada peneliti lain yang berminat melakukan penelitian dengan variabel terikat yang sama, disarankan untuk meneliti variabel bebas lain yang secara teoretis dapat memberikan kontribusi yang lebih besar pada kecemasan menghadapi dunia kerja seperti prokrastinasi akademik, kontrol diri, self-efficacy, dan kematangan karir. Selain itu disarankan untuk dapat mengawasi atau mendampingi subjek penelitian secara langsung sampai dengan selesai mengisi skala 
agar hasil penelitian lebih akurat.

Dapat disimpulkan dari hasil penelitian ini bahwa terdapat hubungan yang negatif antara regulasi diri dengan kecemasan menghadapi dunia kerja. Hal ini mengindikasikan bahwa semakin tinggi regulasi diri maka semakin rendah kecemasan menghadapi dunia kerja ataupun sebaliknya.

\section{Daftar Pustaka}

Abdurofiq, A. (2015). Menakar pengaruh masyarakat ekonomi ASEAN 2015 terhadap pembangunan Indonesia. Salam Jurnal Filsafat Dan Budaya Hukum, 2(1), 249-256.

Alloy, L. B., Riskind, J. H., \& Manos, M. J. (2005). Abnormal Psychology: Current Perspective (9th Edition). New York: McGraw Hill.

Azwar, S. (2013). Realibilitas dan Validitas (Edisi 4). Yogyakarta: Pustaka Pelajar.

Baumeister, R. F., \& Heatherton, T. F. (1996). Self-regulation failure: An overview. Psychological Inquiry, 7(1), 1-15.

Baumeister, R. F., \& Vohs, K. D. (2007). Self regulation, ego depletion \& motivation. Social \& Personality Psychology Compass, 1, 1-13.

Calhoun, J. F., \& Acocella, J. R. (1990). Psychology of Adjustment and Human Relationship. New York: McGraw-Hill.

Carver, C. S. (2004). Self-regulation of action and affect. In R. F. Baumeister \& K. D. Vohs (Eds.). Handbook of SelfRegulation: Research, Theory, and Applications (hal. 13-39). New York: Guilford Press.

Cervone, D., \& Lawrence, A. P. (2012).
Kepribadian: Teori dan Penelitian (Edisi 1). Jakarta: Salemba Humanika.

Dinas Tenaga Kerja dan Mobilitas Penduduk Aceh. (2015). Bom Waktu Pengangguran Aceh. Diakses melalui http://disnakermobduk.acehprov.go.id/i nformasi/117/bom-waktu-penganggu ran-aceh.html.

Durand, V. M., \& Barlow, D.H. (2007). Essentials of Abnormal Psychology. Yogyakarta: Pustaka Pelajar.

Fiske, S. T., \& Taylor, S. E. (1991). Social Cognition. New York: McGraw Hill.

King, L. A. (2010). Psikologi Umum Sebuah Pandangan Apresiatif (Edisi 1). Jakarta : Salemba Humanika.

Klenk, M., Strauman, T. J., \& Higgins, E. T. (2011). Regulatory focus and anxiety: A self-regulatory model of GADDepression comorbidity. Personality \& Individual Differences, 50(7), 935-943.

Kowalski, R. M., \& Leary, M. R. (2000). The Social Psychology of Emotional and Behavioural Problems. Washington DC: American Psychologycal Assiciation.

Lestari, W. A. (2006). Hubungan antara kepercayaan diri dengan kecemasan menghadapi dunia kerja pada mahasiswa Psikologi Universitas Islam Indonesia. Skripsi. Universitas Islam Indonesia: Yogyakarta.

Lutfa, U., \& Maliya, A. (2008). Faktor-faktor yang mempengaruhi kecemasan pasien dalam tindakan kemoterapi di Rumah Sakit Dr. Moewardi Surakarta. Berita Ilmu Keperawatan, 1(4), 187-192.

Malau, M. T. (2014). Aspek hukum perarturan dan kebijakan pemerintah Indonesia 
menghadapi liberalisasi ekonomi regional: Masyarakat Ekonomi ASEAN 2015. Jurnal Rechtsvinding: Media Pembinaan Hukum Nasional, 3(2), 163 182.

Neal, D. J., \& Carey, K. B. (2005). A followup psychometrics analysis of the selfregulation questionnaire. National Institutes Of Health: Public Access, 19(4), 414-422.

Patton, W., Bartrum, D. A., \& Creed, A. A. (2004). Gender differences for optimism, self esteem, expectations and goals in predicting career planning and exploration in adolescents. International Journal for Educational and Vocational Guidance, 4(3), 193-209.

Rodebaugh, T. L., \& Heimberg, R.G. (2005). Combined treatment for social anxiety disorder. Journal of Cognitive Psychotherapy: An International Quarterly, 19, 331-345.

Rostanti, Q., \& Alamsyah, I. E. (2015, November 25). Produktivitas tenaga kerja Indonesia, Republika. Diakses melalui http://nasional.republika.co.id/ berita/nasional/umum/15/11/25/nycpa5

349-produktivitas-tenaga-kerjaindonesia-masih-kalah-dibandingnegara-lain.

Saidah, S. K. (2013). Perbedaan tingkat fear of success pada sarjana perempuan Psikologi IAIN Sunan Ampel Surabaya ditinjau dari demografi. Skripsi. IAIN Sunan Ample: Surabaya.

Sari, D. Y., \& Astuti, T. P. (2014). Kecemasan menghadapi dunia kerja ditinjau dari konsep diri pada mahasiswa tingkat akhir. Empati Jurnal Karya Ilmiah S1, 1(1), 1-12.
Sugianto. (2006). Implikasi pengangguran terhadap pembangunan nasional serta strategi pemecahannya. Value Added, 2(2), 1-17.

Sugiyono. (2010). Metode Penelitian Kuantitatif dan RND. Bandung: Alfabeta.

Sukidjo. (2005). Peran kewirausahaan dalam mengatasi pengangguran di Indonesia. Jurnal Ekonomia, 1(1), 17-28.

Wulandary, D. A. A. (2011). Tingkat kecemasan akan kegagalan menghadapi persaingan dunia kerja ditinjau dari jenis kelamin. Skripsi. Universitas Semarang: Semarang. 